\title{
JAKIEJ TRADYCJI POLACY POTRZEBUJĄ? REKONSTRUKCJE, CELEBRACJE, PROTESTACJE, ZADYMY
}

DANUTA DĄBROWSKA Instytut Polonistyki i Kulturoznawstwa Uniwersytetu Szczecińskiego; The Institute of Polish and Cultural studies of the University of Szczecin e-mail: dada@tstd.pl

Tytuł mojego artykułu w sposób oczywisty nawiązuje do książki Jerzego Jedlickiego Jakiej cywilizacji Polacy potrzebuja, która ukazała się w 1988 roku, a więc u schyłku PRL-u. Była to wówczas bardzo ważna książka, podejmowała bowiem generalny krąg pytań dotyczących polskiej tożsamości na przestrzeni wieków. Ważny był także moment jej wydania - jeszcze nie bardzo wiadomo było, jak to się stanie, ale narastała pewność, że coś się jednak musi całościowo zmienić, bo ustrój dogorywał, opozycja się wypalała, gospodarka wydawała ostatnie tchnienie. Poczynając od XVIII wieku, często jednak sięgając jeszcze głębiej, Jedlicki rekonstruował podstawowe pary opozycji wyznaczające europejski, ale przede wszystkim polski dyskurs dotyczący teraźniejszości i przyszłości. Pisał:

W wielkim dziewiętnastowiecznym sporze o cywilizację wyróżnić można pewne problemowe płaszczyzny i każdej z nich nadać nazwę złożoną z dwóch przeciwstawnych sobie ówcześnie haseł. Będą to takie opozycje, jak: „narodowość i cywilizacja”, ,rozwój naturalny i sztuczny”, ,,postęp moralny i materialny” (albo równoważnie „ewangelia i ekonomia”), „Słowiańszczyzna i Zachód” itp. ${ }^{1}$

${ }^{1}$ J. Jedlicki, Jakiej cywilizacji Polacy potrzebują. Studia z dziejów idei $i$ wyobraźni XIX wieku, Warszawa 1988, s. 12. 
Spór ten nigdy nie został rozstrzygnięty, bo chyba rozstrzygnąc się go nie da. Jego istotą jest bowiem nierównoważność poszczególnych członów opozycji, ich poniekąd nieprzystawalność. Z jednej strony występują w nim idee i wartości nacechowane bardzo emocjonalnie, z drugiej zaś chłodna pragmatyka i racjonalne podejście do rzeczywistości, pozbawione złudzeń, wymagające rzeczowej kalkulacji oraz wyzbycia się uczuć i sentymentów. Oczywiście dla potrzeb niniejszego szkicu wyostrzam i ujednoznaczniam omawiane kwestie, ale nie zmienia to istoty rzeczy, którą można ująć, sięgając znów do książki Jedlickiego. Omawiając kształtujące się ostatecznie w wieku XIX dwie główne tendencje w polskim myśleniu, autor stwierdzał:

I odtąd mamy dwie historie kultury. Świętą historię narodu, jego pieśni, więzień i pobojowisk. I powszechną historię społeczeństwa, historię siewów i zbiorów. A jeszcze historię myśli politycznej, skazanej na bezradne szamotanie się między archanielską wizją przeszłości i przyszłości a zgrzebną rzeczywistością małego tygodnia Polaków².

Wspomniany dyskurs toczył się ze zmiennym nasileniem przez cały wiek XIX, ale nie wygasł także w momencie odzyskania niepodległości w 1918 roku, a może nawet przybrał wówczas na sile, dotyczył wszak państwa, które powstawało z politycznego niebytu i którego naród musiał się określić w swojej poniekąd nowej tożsamości. Rozstrzygnięć wymagały nie tylko kwestie ustrojowe, prawne i gospodarcze, lecz także, a może przede wszystkim, duchowy kształt nowego państwa tworzony przez wybór tradycji i realizowany w społecznej pedagogice. Jego sprawdzianem okazały się postawy i działania Polaków w czasie II wojny światowej dostarczające argumentów obu stronom sporu wtedy, gdy on trwała i wtedy, gdy się skończył. Okres PRL-u jednak zniweczył właściwie zupełnie możliwość publi-cznego dyskursu, spychając go do „podziemia” - w sferę debat i wyborów

\footnotetext{
${ }^{2}$ Ibidem, s. 76.
} 
dokonywanych w rodzinach, kręgach przyjacielskich, środowiskach katolickich, potem w obrębie ugrupowań opozycyjnych.

To telegraficzne przypomnienie jest tu konieczne, bo obecne wybory, postawy i żarliwe spory światopoglądowe mają swoje korzenie w tej odległej przeszłości, która też konstytuowała wszystkie powojenne wystąpienia i protesty, a przede wszystkim doszła do głosu w czasie sierpniowych strajków 1980 roku i w kulturze solidarnościowej. Pamiętając więc o odległych początkach sporu, pragnę się skupić na tej bliżzzej nam rzeczywistości.

Na przełomie XX i XXI wieku mamy do czynienia w kulturze polskiej $\mathrm{z}$ dwoma różnymi mitami założycielskimi, dla których stosunek do przeszłości i wybory dokonywane na gruncie tradycji okazują się bardzo istotne. Można by nawet powiedzieć, że stanowią podstawę owych mitów - tradycja funkcjonuje tu jako tekst, który domaga się odczytania, bo w zależności od sposobu lektury projektuje teraźniejszość i przyszłość. Pierwszym mitem założycielskim są strajki 1980 roku i rodzący się wówczas model kultury solidarnościowej, który zdominuje myślenie, nie tylko opozycyjne, na całą dekadę lat osiemdziesiątych. W świadomości wielu Polaków Sierpień 1980 roku jest przełomem, początkiem prowadzonej na szeroką skalę walki z systemem komunistycznym. $\mathrm{Z}$ jednej strony ujawnia się w takim ujęciu nikła wiedza o wcześniejszych działaniach opozycyjnych, z drugiej zaś owe wcześniejsze działania traktuje się jako preludium do sierpniowego buntu, który je niejako „wchłania”, instytucjonalizuje. Wytwarza się wówczas, obecne w potocznej świadomości, ale podkreślane przede wszystkim przez kulturę opozycyjną, przekonanie o dualistycznym charakterze polskiej wspólnoty, o ostrych podziałach na „my” i „oni” grożących wręcz rozpadem wspólnoty. Owo „my” ustanawiali ci, którzy dotychczas pozbawieni byli możliwości artykułowania swoich odczuć, poglądów i wartości w sferze publicznej. Chcąc w niej zaistnieć w opozycji do „onych” - władzy i jej popleczników, muszą uzyskać legitymację dającą społeczne poparcie dla rodzącego się ruchu, a to możliwe jest przede wszystkim poprzez budowanie uniwersum symboli, 
mitów, znaków tradycji, kodów kulturowych, które będą powszechnie czytelne i które nie będą z kolei kojarzone ani z kulturą oficjalną, ani tym bardziej z językiem i kodami reprezentowanymi przez władzę. Występuje tutaj jednocześnie dążność do zacierania różnic pomiędzy poszczególnymi grupami opozycji na rzecz tworzenia modelu monolitycznego narodu przeciwstawianego władzy.

Poszukiwanie własnej legitymacji odbywało się przede wszystkim poprzez odwołania do tradycji romantycznej i postromantycznej, w mniejszym stopniu pojawiały się tutaj elementy innych kodów wywodzących się z folkloru politycznego o sarmackich korzeniach czy języka poezji rewolucyjnej; były one jednak także w rozmaity sposób powiązane z głównym nurtem o proweniencji romantycznej. Ważną cechą tak pojmowanej tradycji była jej wyraźna ahistoryczność, nakładanie się na siebie i współwystępowanie elementów związanych z różnymi historycznymi wydarzeniami będącymi podstawą narodowych mitów. Na te aspekty stosunku do tradycji i dokonywanych wówczas wyborów zwracał uwagę Sergiusz Kowalski, pisząc:

Tradycja zanurza swe korzenie w przedkomunistycznej przeszłości, ogólniej: w tym, co polskie, a nie „peerelowskie”. Przeszłość stanowi źródło wiedzy o tym, jakie naprawdę jest i było polskie społeczeństwo; tradycja przekazuje ponadczasową istotę wspólnoty narodowej ${ }^{3}$.

Owa „istota” konstruowana jest tak, aby podkreślić inność, odmienność, obcość tego wszystkiego, co w sferze tradycji, mitów i wartości z nimi związanych proponował PRL, a co tak naprawdę pojmowane jest tutaj jako zamazywanie, niszczenie, odbieranie Polakom tego, co od zawsze stanowiło o naszej tożsamości. Toteż proces wyboru tradycji przez kulturę solidarnościową jest nie tyle i nie tylko kwestią wyboru innych niż PRL-owskie treści,

${ }^{3}$ S. Kowalski, Krytyka solidarnościowego rozumu. Studium z socjologii myślenia politycznego, Warszawa 1990, s. 80. 
ile przypominaniem, odzyskiwaniem, przywracaniem obszarów przeszłości, wydarzeń i związanych z nimi narracji, które w dyskursie PRL-owskim były nieobecne czy też zbyt słabo obecne, traktowane jako niewygodne, zabronione, skazane na wykluczenie ze społecznej pamięci. Dobitnie ten proces podsumowuje Sergiusz Kowalski, stwierdzając, że „,budowanie nowego społeczeństwa nie jest tworzeniem, ale odtwarzaniem"4. To zaś, co ma być odtworzone, sytuuje się z reguły po jednej stronie sporu opisywanego przez Jerzego Jedlickiego - po stronie ,świętej historii narodu, jego pieśni, więzień i pobojowisk”, wyznaczając jednocześnie specyfikę polskiej rewolucji, która nie tyle chce zaczynać od początku, ile odzyskać mityczny ład utracony. Składają się na niego takie elementy, jak: polski katolicyzm wraz z proponowanymi przez niego kanonami etycznymi i często wspierający tendencje mesjanistyczne, dzieje walk o niepodległość i idea powstania jako sposobu wybijania się na ową niepodległość, mit jedności, monolityczności narodu, wzory postaw jednostkowych i zbiorowych przekute w stereotypowe scenariusze uruchamiane zawsze w sytuacji zagrożenia. Przede wszystkim jednak dominuje tutaj przekonanie o ustawicznie powtarzających się wydarzeniach wymagających przyjmowania stale tych samych postaw i dokonywania tych samych wyborów, co w oczywisty sposób uniemożliwia myślenie historyczne i dostrzeganie tego, co jednostkowe i wyjątkowe, co stanowi o premierowości w otaczającym Polaków świecie, a w dalszej kolejności wyznacza umiejętność reagowania na tę rzeczywistość inaczej, niż poprzez szukanie analogii w tym, co znane i oswojone. Można by ten sposób myślenia i reagowania na historię zestawić z romantycznymi tendencjami do umityczniania historii, które najpełniejszy wyraz znajdują w systemach mesjanistycznych, szczególnie tym proponowanym przez Mickiewicza.

Drugim mitem założycielskim stały się obrady Okrągłego Stołu i wypracowany wówczas kompromis między dotychczasową władzą a środowiskami

\footnotetext{
${ }^{4}$ Ibidem, s. 79.
} 
opozycyjnymi. Demokratyczne wybory i szybko zmieniające się realia polityczne, społeczne i gospodarcze musiały w tej sytuacji, po chwilowej euforii, spowodować poczucie zagubienia, chaosu, pewnej nawet opresji wynikającej z przymusu nowego typu aktywności. Naród rozpoznający się dotychczas przede wszystkim poprzez kulturę klęski nagle musiał zaistnieć w sytuacji zwycięstwa, zdefiniować sukces, przejść jakby na drugą stronę odwiecznego sporu. Niezbędne w tym procesie okazywało się także przekształcenie pożądanej dla nowego typu wspólnoty tradycji. To wszystko, co z takim trudem odzyskiwano przez dekadę lat osiemdziesiątych, stawało się w pewnym sensie balastem, który uniemożliwiał czy też poważnie utrudniał transformację, toteż lata dziewięćdziesiąte są okresem załamywania się romantycznego paradygmatu patriotyczno-niepodległościowego, co oczywiście widać np. w literaturze tego czasu, ale co chyba najlepiej uwidacznia się w nowym języku mediów. Powraca w nich pozytywistyczne słowo „społeczeństwo” coraz częściej zastępujące romantyczny „naród”, niemal zupełnie znika „ojczyzna”, karierę robią zupełnie nowe słowa, takie jak: „transformacja”, „demokratyzacja”, ,rynek”, ,marketing”, ,poprawność polityczna” itp.

Szybko jednak okazało się, że trudno jest znaleźć w kulturze polskiej, szeroko rozumianej, te alternatywne obszary tradycji, które mogłyby stać się podstawą nowego projektu polskiej duchowości - tej spod znaku transformacji ustrojowej, otwarcia na świat z całą jego różnorodnością we wszystkich dziedzinach życia, polskiej duchowości w zjednoczonej Europie wreszcie. Sprawę komplikują dodatkowo ujawnione z ogromną siłą po 1989 roku wewnętrzne polityczne podziały, wielość opcji światopoglądowych, w kulturze solidarnościowej spychane na margines w imię idei wspólnego wroga, któremu przeciwstawia się narodowy monolit. Spór o kształt nowej polskiej duchowości i wspierającej ją tradycji przebiega na kilku przynajmniej płaszczyznach, z których najbardziej spektakularne i medializowane są te, reprezentowane przez poszczególne partie polityczne. Ale jego występowanie uwarunkowane jest też np. przez pokoleniową przynależność, jednostkowe 
doświadczenia Polaków, tradycję rodzinną itp., a co za tym idzie, przez różne zasoby wspólnotowej i indywidualnej pamięci.

Istnieje zatem tradycja oficjalna i partyjna, nagłaśniane medialnie społeczne spektakle odbywające się w sferze publicznej, ale też inna tradycja, tworzona przez mniejsze wspólnoty, które szukają w niej uzasadnień dla własnej działalności i własnych wyborów w sferze wartości. Znanemu już z okresu PRL-u zawłaszczaniu tradycji przez politykę towarzyszy przy tym często zjawisko, które można by nazwać tabloidyzacją przeszłości, a więc jej skrajnym upraszczaniem, nastawieniem na punktowe, wydarzeniowe prezentowanie z zatarciem wszelkich związków przyczynowo-skutkowych, głębszej refleksji czy uniemożliwieniem dyskursu. Mamy więc do czynienia nie tyle z systemowym wyborem tradycji, która służyłaby budowaniu narodowego kanonu kultury i sprzyjała jakiemuś tożsamościowemu porządkowi mogącemu powstać na gruzach peerelowskiej doktryny, ile z wielością wyborów i wielością ich kryteriów, powodującą trudności w porozumiewaniu się Polaków, a czasem ostre konflikty między nimi. Pamiętać przy tym należałoby o pewnej prawidłowości wskazanej przez Ewę Domańską we wstępie do książki Haydena White'a Poetyka pisarstwa historycznego:

Każde przedstawienie przeszłości jest skażone ideologią, zaś ci badacze, którzy wytykają ideologiczność innym, robią to nie po to, by sami mogli przedstawić przeszłość w sposób bardziej „obiektywny”, lecz dlatego, że prezentują inną opcję polityczną czy inny światopogląd $\mathrm{d}^{5}$.

Spośród wielu obecnych dziś w Polsce dyskursów dotyczących tradycji chciałabym, przykładowo, przybliżyć niektóre, uznane przeze mnie za najbardziej charakterystyczne czy też szczególnie silnie obecne w zbiorowej

${ }^{5}$ E. Domańska, Wstepp, [w:] H. White, Poetyka pisarstwa historycznego, pod red. E. Domańskiej i M.Wilczyńskiego, Kraków 2000, s. 27. 
świadomości. Najlepiej zaś przyjrzeć się im poprzez społeczne spektakle odbywające się w przestrzeni publicznej i zawarty w nich przekaz symboliczny.

Zacząc wypada od tych oficjalnych, reżyserowanych przez władzę państwową, a więc przede wszystkim rytuałów i celebracji rocznic, odsłaniania pomników, obchodów świąt. Tutaj mamy do czynienia z wyraźnym i względnie spójnym wyborem tradycji, najogólniej mówiąc, niepodległościowej i patriotycznej, często powielającej wzory wypracowane w kulturze opozycyjnej, którym teraz nadaje się państwową rangę. Ciąg tradycji budowany jest w tym przypadku na historii powstań - od listopadowego po warszawskie, kulcie bohaterów, miejsc, przełomowych lub po prostu ważnych wydarzeń z nimi związanych. W tym nurcie umieszczane są także wystąpienia robotnicze z okresu PRL-u, strajki sierpniowe i stan wojenny. Te ostatnie wydarzenia jako najbliższe czasowo i tworzące mit założycielski współczesnej Polski są szczególnie ważne, ale zwykle nie istnieją jako coś osobnego, raczej pokazywane są w kontekście długiej tradycji „wybijania się na niepodległość" i trwałej, chlubnej postawy wielu pokoleń podejmujących ustawicznie ten sam patriotyczny obowiązek.Celem tak pojmowanych obchodów jest oczywiście skupianie wspólnoty wokół określonej koncepcji historii, owego „dziedzictwa”, któremu współcześni winni są szacunek i w którym współczesność szuka zakorzenienia. Nie bez znaczenia jest jednak fakt, że wybory z tradycji dokonywane są zawsze z punktu widzenia dnia dzisiejszego i najczęściej służą politykom do wygłaszania doraźnych deklaracji ideologicznych, w pewnym sensie zatem ważna jest nie sama konkretna data, postać historyczna czy wydarzenie, ale sposób dzisiejszego o nich opowiadania - takiego, które ma się nam dzisiaj przydać, dzisiaj i które w naszej codzienności ma być zrozumiałe. Jak słusznie pisał Robert Traba:

elita stwarza takie znaki, symbole czy rytuały rocznicowe, które stara się wprowadzić do powszechnego obiegu, aby wokół nich zbudować jedność wspólnoty. W tym sensie rocznice się „wymyśla”, ale jednocześnie musi istnieć emocjonalny związek z taką datą, który później utrwala 
się przez systematyczne obchody. [...] Jest czymś naturalnym, że pewne rocznice kreuje się z punktu widzenia potrzeb dnia obecnego. Gdy się ,,pisze" pamięć zbiorową, to jest ona odzwierciedleniem pewnej koniunktury politycznej i społecznej, a nie zapisem wydarzeń sprzed lat ${ }^{6}$.

Autor zwraca przy tym uwagę, że oficjalnie dokonywane wybory i przypisane do nich narracje muszą wywoływać kontrowersje, ponieważ zwykle wynikają z aktualnej politycznej koniunktury, nie ma bowiem czegoś takiego, jak „obiektywnie ważne” wydarzenia, które w sposób bezdyskusyjny uznane mogłyby być przez ogół za ważne. A jeśli nawet większość z owymi wyborami się zgadza, kontrowersje pojawiają się wokół sposobu mówienia o nich, wokół wyboru tej, a nie innej narracji. Najlepszym przykładem mogą tu być obchody kolejnych rocznic zakończenia strajków w stoczniach w 1980 roku. Można by się zastanawiać, czy nadal chodzi tutaj o tradycję i dokonywane w jej obrębie wybory, czy też wyłącznie o politykę historyczną, co jest już zupełnie innym zagadnieniem.

Charakterystyczną cechą współczesnych celebracji rocznicowych, wyraźnie odróżniającą je od tych PRL-owskich, jest każdorazowe wpisywanie ich w kontekst sakralny, spajanie wartości patriotycznych z religijnymi, tak przecież znamienne dla romantycznej religii patriotyzmu. Obecność hierarchów kościelnych, msze polowe i święcenie pomników to nieodłączne elementy państwowej celebry, w sposób pośredni uwznioślające także jej współczesnych organizatorów i uczestników. Mamy tu do czynienia z odwołaniami do religii chrześcijańskiej, do katolicyzmu jako spoiwa wspólnotowego, które pozwalało przetrwać w czasach niewoli i określało przez wieki polską tożsamość. Warto jednak zwrócić uwagę, że w tak pojmowanej wspólnocie istnieje $\mathrm{z}$ jednej strony definiowanie Polaka jako katolika, z drugiej zaś, wprost lub pośrednio, wykluczanie z owej wspólnoty ateistów

${ }^{6} \mathrm{R}$. Traba, Przeszłość w teraźniejszości. Polskie spory o historię na początku XXI wieku, Poznań 2009, s. 28, 29. 
i przedstawicieli innych wyznań. A to z kolei kłóci się z oficjalnie deklarowanym pluralizmem, wolnością jednostki, europejską zasadą tolerancji i wyraźnego rozdzielenia państwa i Kościoła.

Owa podniosłość i oficjalność, patos i sakralizacja jako metody społecznej pedagogiki stwarzają jednak duży dystans między celebrantami a pozostałymi uczestnikami, którym wyznacza się tu rolę widzów, uczniów, apelując do ich emocji i licząc na zapamiętanie lekcji. Dystans ten wyraźnie maleje albo zupełnie znika w innych formach utrwalania wybranych z tradycji treści takich, jak $-\mathrm{z}$ jednej strony nowoczesne multimedialne muzea, $\mathrm{z}$ drugiej zaś rekonstrukcje historyczne. Muzeum Powstania Warszawskiego czy powstające w Szczecinie Muzeum Przełomów mają pełnić nie tylko funkcję przechowywania i pokazywania narodowych relikwii, ale przede wszystkim mają stwarzać możliwość ponownego przeżycia wydarzeń z przeszłości, a przez to utożsamienia się emocjonalnego $\mathrm{z}$ tradycją. Podobnym celom służą, tak obecnie częste, rekonstrukcje historyczne, będące bardzo dobrym przykładem nie tyle zakorzeniania się współczesności w tradycji czy podejmowania z nią dyskusji, ile wspomnianej wyżej tabloidyzacji przeszłości. Swego czasu Zdzisław Pietrasik w artykule pod znamiennym tytułem Jaka przeszłość nas czeka? pisał, przywołując kolejne przykłady takich właśnie rekonstrukcji:

Jesteśmy więc $\mathrm{w}$ teatrze (czasem $\mathrm{w}$ operetce) historii, inscenizujemy „żywe obrazy”, na których nic nieoczekiwanego wydarzyć się nie może. Tak prezentowane dzieje przypominają coraz bardziej komiks?

Doskonale też uchwycił Pietrasik bliski związek rekonstrukcji wybranych wydarzeń z przeszłości z aktualnie wówczas toczącą się kampanią wyborczą, w której politycy różnych opcji nader chętnie w ów spektakl się wpisywali, odgrywali w nim sentymentalno-patriotyczne role i posługiwali się

${ }^{7}$ Z. Pietrasik, Jaka przesztość nas czeka?, „Polityka” 2005, nr 33, s. 28. 
sprawdzonymi rekwizytami - vide szabla Andrzeja Leppera. Z jednej strony mamy tu zatem do czynienia z ludyczną, karnawałową wersją tradycji, z drugiej zaś z jej zawłaszczeniami przez politykę. W obu przypadkach sferą odwołań pozostają emocje, sentymenty, kompensacja rozmaitych niedogodności dnia codziennego, a w płaszczyźnie symbolicznej ograne, doskonale rozpoznawalne rekwizyty z przeszłości, które tak naprawdę przestają już coś znaczyć wyrwane ze swoich macierzystych kontekstów i ułożone w mozaikę tworzącą scenografię publicznych spektakli.

Nieco inny porządek dyskursu współczesności z tradycją odnajdujemy w rozlicznych akcjach protestacyjnych, ulicznych manifestacjach, marszach protestu albo poparcia, organizowanych przez związki zawodowe, stowarzyszenia społeczne, grupy pracowników konkretnych zakładów czy branż lub też rodzące się w pewnym sensie spontanicznie pod wpływem bulwersujących zbiorowość wydarzeń. Jakkolwiek tego typu wystąpienia często również, mniej lub bardziej oficjalnie, inspirowane są lub sterowane przez ugrupowania polityczne, to jednak na ogół dąży się w nich do stworzenia wrażenia ruchów oddolnych, będących głosem społeczeństwa, a nie władzy. Ujawniane w akcjach protestacyjnych nawiązania do tradycji trzeba umieścić w dwóch różnych kręgach, odwołujących się do obu wspomnianych przez Jedlickiego członów opozycji.

$\mathrm{Z}$ jednej strony mamy tu do czynienia $\mathrm{z}$ tworzeniem zupełnie nowej tradycji, odnoszącej się dość luźno do tych okresów z przeszłości, w których podkreśla się polską tolerancję, ale przede wszystkim mającej służyć otwarciu na światowe standardy, w pewnym sensie „cywilizowaniu” Polaków i przełamywaniu zakorzenionych w mentalności zbiorowej schematów, wartości czy postaw. Przykładem mogą być parady równości, wszelkiego typu demonstracje solidarności z różnorakimi mniejszościami odbywające się pod hasłami tolerancji i równouprawnienia. Mobilizowane przy tej okazji siły porządkowe, które i tak nie zawsze są zdolne zapobiec atakom na takie manifestacje, najlepiej dowodzą, że nie jest to jeszcze tradycja ogółowi 
Polaków bliska. Raczej odczytywana jest jako zagrożenie dla „prawdziwych" wartości, jakie ujawniane są i jakich broni się w różnorodnych akcjach protestacyjnych. Z drugiej więc strony wspólnota skupia się wokół tych symboli i kodów przeszłości, które uznawane są za „nasze”, polskie, od zawsze niemal wyznaczające polską tożsamość teraz wystawioną na próbę jej zniszczenia. Znowu mamy do czynienia przede wszystkim z nawiązaniami - na różnych poziomach - do świętej historii walk i męczeństwa, tyle że wroga zewnętrznego zastępuje często aktualny minister, zarząd spółki, dyrektor zakładu pracy, władze samorządowe lub państwowe, czasem sytuowany jest on w Brukseli jako synonimie Unii Europejskiej.

Do rozstrzygania doraźnych partykularnych sporów między grupami interesów wykorzystywany zostaje cały arsenał znanych i łatwo czytelnych symboli, strajk w obronie miejsc pracy wpisywany jest w ciąg powstań narodowych, barykady i palenie opon dają namiastkę obrony reduty, a współczesną wersją narodowego teatru okazuje się bitwa warszawska między kupcami sprzed Pałacu Kultury i wspieranymi przez policję ochroniarzami. Wydarzenie to relacjonował Juliusz Ćwieluch na łamach „Polityki”:

Tak więc 21 lipca 2009 r. o godz. 7.30 na komornika czekały trzy rzędy kobiet skandujących do ochroniarzy: gestapo, gestapo! Nad nimi powiewały polskie flagi, przewiązane kirem. Tragedia na placu Defilad miała być tragedią wszystkich Polaków, którzy ciemiężeni są przez państwo (niczym zaborcę). A gdyby ktoś miał jeszcze wątpliwości, że nie chodzi tu o zyski ze sprzedaży dżinsów, chińskich tekstyliów i butów, ale o wolną Polskę, odśpiewano Rotę. Z naciskiem na pierwsze i środkowe zdanie: „Nie rzucim ziemi, skąd nasz ród” i „Twierdzą nam będzie każdy próg”.

Podobnych przykładów można by znaleźć bardzo wiele. Pokazują one trywializację i nadużycia w wykorzystywaniu symboliki narodowej i państwowej - flagi, godła, hymnu - manipulowanie tradycją przykrawaną do doraźnych

${ }^{8}$ J. Ćwieluch, Teatr narodowy, „Polityka” 2009, nr 31, s. 12. 
potrzeb. Roch Sulima ${ }^{9}$ mówi też o „rytuale jako formie skradzionej” i jej dominacji w kulturze współczesnej, szczególnie właśnie w typie spektakli publicznych, gdzie liczą się spektakularne gesty, czytelne symbole, żywe obrazy tak chętnie potem pokazywane w mediach. W ten sposób zresztą nadbudowywany jest kolejny spektakl. Tworzy się widowisko medialne, którego narracja wyznacza sposób przeżywania i doznawania tego, co zostało zarejestrowane przez kamery.

W całej pełni rytuały wywodzące się z tradycji romantycznych i postromantycznych występują w sytuacjach klęsk i katastrof takich jak katastrofa samolotu pod Smoleńskiem. Zostały one już dość dokładnie przeanalizowane, tutaj więc jedynie je sygnalizuję. Przy okazji tych wszystkich tragicznych wydarzeń uruchamiany zostaje natychmiast mechanizm dobrze wypróbowanych reakcji, określonych swego czasu przez Marię Janion jako kultura klęski. Ofiary klęsk żywiołowych, wypadków lotniczych czy drogowych zostają uwznioślone, przydaje im się palmę męczeństwa, a ogłaszana natychmiast po dramatycznym wydarzeniu żałoba narodowa czyni z niego narodową tragedię, którą nader łatwo zestawiać z innymi narodowymi klęskami, w jakie obfitowała nasza historia i nasza zbiorowa mitologia.

$\mathrm{Na}$ zupełnie innym biegunie należałoby umieścić typ społecznych spektakli nazywanych potocznie ,zadymami”. Są to oczywiście bijatyki stadionowych pseudokibiców, ale mieszczą się w tym typie także różnorodne akcje protestacyjne przybierające charakter bezpośredniego starcia ulicznego, nastawione na agresję, a nie na kompromisowe poszukiwanie rozwiązań. Palenie opon przed Sejmem lub gmachami ministerstw, a w lokalnym wydaniu - przed siedzibami wojewodów bądź władz samorządowych, agresja skierowana pod adresem sił porządkowych, regularne uliczne bitwy, do których dochodzi podczas demonstracji - to tylko niektóre przykłady tego rodzaju społecznych spektakli. Mamy w nich do czynienia z pomieszaniem

\footnotetext{
${ }^{9}$ R. Sulima, Krok w tyt, dwa kroki w przód, „Polityka” 2010, nr 19, s. 24.
} 
różnych porządków, także tych symbolicznych, ale przede wszystkim z zakłóceniem hierarchii ważności i doniosłości wydarzeń. Ujawnia się w owych „zadymach” cały tradycyjny arsenał patriotyczno-rewolucyjnych odwołań, znaków i symboli, które zostają ze sobą przemieszane i których używa się dość dowolnie. Narodowe barwy, szczytne hasła, słowa hymnu państwowego i pieśni religijnych pojawiają się obok palonych opon, kamieni, wyzwisk i przepychanek jako pewien stały scenariusz - mniej nawet ważne, jakich wydarzeń. Mogą bowiem dotyczyć zarówno utraty miejsc pracy w likwidowanej fabryce czy zbyt niskich płac, jak i zupełnie lokalnych, partykularnych i ambicjonalnych sporów, budowy parkingu, obwodnicy itp.

We wszystkich przywołanych przykładach mamy do czynienia ze stale obecną w polskiej świadomości tradycją oporu, walki, których romantyczny rodowód i postromantyczne warianty są oczywiste. Nie znaczy to jednak, że nic się nie zmienia w sposobach funkcjonowania owego paradygmatu. Wszystko wskazuje na to, że przestaje być on żywy w sensie nośnika wartości rzeczywiście wyznawanych i uznawanych przez narodową wspólnotę. Jeśli nadal w jakiś sposób służy naszej tożsamości, to bardziej jako forma czy zespół form, łatwych i czytelnych przy braku alternatywnych scenariuszy zachowań, które byłyby równie skuteczne. Często wręcz zastępuje poszukiwania w sferze myślenia o naszej duchowości we współczesnym świecie. Jeśli prawdą jest, że świat ponowoczesny charakteryzuje się wyjątkową zdolnością do zapominania, to w opisywanych przypadkach mielibyśmy do czynienia z zapomnieniem treści, które tworzyły w przeszłości polską formę, czy może nieco ostrożniej - $\mathrm{z}$ ich unieważnieniem w zupełnie innej historycznej rzeczywistości. Pozostała więc sama forma, coś na kształt teatralnych dekoracji, rekwizytów i ról odgrywanych mechanicznie. Jednocześnie nie bardzo potrafimy stworzyć inne dekoracje i napisać inne role.

Jednoznaczna odpowiedź na pytanie - jakiej tradycji Polacy potrzebują? - nie jest więc chyba ani prosta, ani nawet możliwa. Wydaje się bowiem, że mieszczą się dziś w tym pojęciu kwestie różnie artykułowane, jednak zawsze 
w bardzo podobny sposób wypowiadane znanym i niezmiennym językiem, który tę różnorodność zamazuje, stwarzając czasem pozory, że wszyscy mówimy jednym głosem, a przynajmniej, że powinniśmy tak mówić. Z jednej strony próby wypracowania innej narracji - o przeszłości, tradycji i współczesności - określane bywają jako zdrada najświętszych narodowych interesów, z drugiej zaś np. Stefan Chwin alarmuje, że „Polaków łączy tylko ból"10. Ciągle zatem pozostajemy w obrębie starego sporu, przy czym żadna z zasygnalizowanych tu opcji nie określa do końca polskiej rzeczywistości. Każda z nich jest jakoś prawdziwa i jednocześnie jakoś fałszywa.

\section{BIBLIOGRAFIA}

Chwin Stefan, Polaków tączy tylko ból. Ze Stefanem Chwinem rozmawia Rafat Kalukin, „Duży Format”, dodatek do „Gazety Wyborczej” 30.04.-3.05.10.

Ćwieluch Juliusz, Teatr narodowy, „Polityka” 2009, nr 31.

Domańska Ewa, Wstęp, [w:] H. White, Poetyka pisarstwa historycznego, pod red. E. Domańskiej i M.Wilczyńskiego, Kraków 2000.

Jedlicki Jerzy, Jakiej cywilizacji Polacy potrzebują. Studia z dziejów idei i wyobraźni XIX wieku, Warszawa 1988.

${ }^{10}$ S. Chwin, Polaków taczy tylko ból. Ze Stefanem Chwinem rozmawia Rafat Kalukin, „Duży Format”, dodatek do „Gazety Wyborczej” 30.04.-3.05.10, s. 2. 
Kowalski Sergiusz, Krytyka solidarnościowego rozumu. Studium z socjologii myślenia politycznego, Warszawa 1990.

Pietrasik Zdzisław, Jaka przeszłość nas czeka?, „Polityka” 2005, nr 33.

Sulima Roch, Krok w tył, dwa kroki w przód, „Polityka” 2010, nr 19.

Traba Robert, Przeszłość w teraźniejszości. Polskie spory o historię na początku XXI wieku, Poznań 2009. 


\section{What Kind of Tradition do the Poles Need? \\ Reconstructions, Celebrations, Protests, Rows}

The article takes the issues of contemporary understanding of cultural tradition and ways of cultivating culture after the 1989 breakthrough. Two basic thesis were accepted, with reference to Jerzy Jedlicki's book entitled Jakiej cywilizacji Polacy potrzebuja. Firstly, two tendencies clash in Polish culture - the conservative and the modernizing one, both present for a long time, but crystallized mainly in the nineteenth century. Secondly, the basic circle of tradition referred to in modern Poland remains the Romantic tradition, properly converted and adapted to the reality of modern Poland. It manifests itself both in the official celebrations of national anniversaries, as well as social protests scenarios and all kinds of historical reconstructions. Romantic cultural codes, symbols, gestures and rituals are used on these occasions. The modernization trends in Polish culture come to the fore especially after the Polish accession to the European Union, but their promotion often encounters various forms of resistance, since they are seen as a threat to Polish identity, understood as founded on patriotic and religious values.

Keywords: Polish cultural tradition, Romantic tradition, protests, celebrations, rituals. 


\section{Nowości Wydawnictwa UKSW}

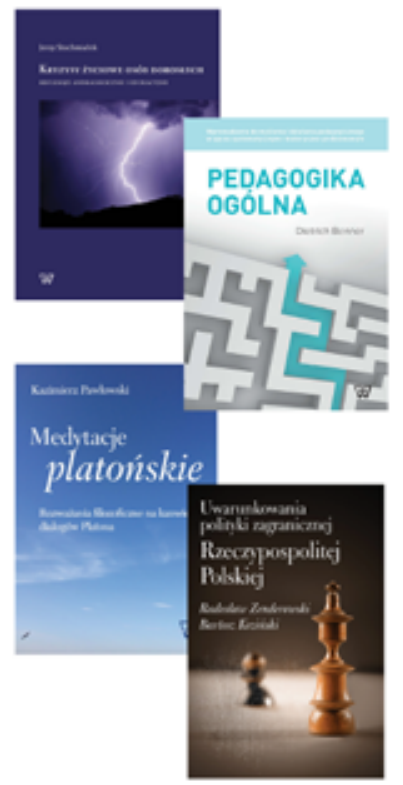

- Jerzy Stochmiałek, Kryzysy życiowe osób dorosłych

- Dietrich Benner, Pedagogika ogólna

- Kazimierz Pawłowski, Medytacje platońskie. Rozważania filozoficzne na kanwie dialogów Platona

- Bartosz Koziński, Radosław Zenderowski, Uwarunkowania polityki zagranicznej Rzeczypospolitej Polskiej

Więcej informacji na stronie: www.wydawnictwo.uksw.edu.pl 